\title{
Persistence and Change: Standards-Based Reform in Nine States
}

Diane Massell

Michael W. Kirst

Margaret Hoppe

Follow this and additional works at: https://repository.upenn.edu/cpre_policybriefs

Part of the Curriculum and Instruction Commons, Educational Methods Commons, Education Policy Commons, and the Urban Education Commons

\section{Recommended Citation}

Massell, Diane; Kirst, Michael W.; and Hoppe, Margaret. (1997). Persistence and Change: StandardsBased Reform in Nine States. CPRE Policy Briefs.

Retrieved from https://repository.upenn.edu/cpre_policybriefs/76

The research presented in this policy brief is part of CPRE's Systemic Reform Study, a joint project conducted by the Policy Center of CPRE in conjunction with the National Center for Research on Teacher Learning (NCRTL). The project was funded by the U.S. Department of Education's Office of Educational Research and Improvement (OERI). View on the CPRE website.

This paper is posted at ScholarlyCommons. https://repository.upenn.edu/cpre_policybriefs/76

For more information, please contact repository@pobox.upenn.edu. 


\title{
Persistence and Change: Standards-Based Reform in Nine States
}

\begin{abstract}
Beginning in the mid-to-late-1980s, state policymakers began to rethink their strategies for influencing curriculum and instruction in public education and adopted a policy strategy known as standards-based, systemic reform.

The rapidity with which the idea of standards-based, systemic reform took hold is remarkable, if not without historical precedent in the strongly networked field of education. Originally incubating quietly in the enclaves of professional subject-matter associations like the National Council of Teachers of Mathematics, efforts to set standards and articulate systemic reforms based on them were soon generated by nearly every state in the union (American Federation of Teachers, 1995) and a large array of urban, suburban and rural districts. Support came from the U.S. Department of Education, the National Science Foundation, and associations as diverse as the Business Roundtable, the National Governors Association, and the American Federation of Teachers. Indeed, standards-based reform enjoyed high bipartisan consensus.
\end{abstract}

But this consensus began to fray somewhat as standards- based reform ideas were translated into real policies. Federal policy efforts, notably Goals 2000 and the reauthorized Elementary Secondary Education Act, and some of the state reforms, occasioned significant debates about the possibility of greater control over localities traditional autonomy in the area of curriculum. For example, Congressional and state-level policymakers strongly challenged such elements as the national panel envisioned by Goals 2000 that would have had the authority to certify the quality of states standards.

This issue of CPRE Policy Briefs takes a look at how, against this backdrop, standards-based, systemic reforms evolved in nine states during the 1994-95 period. Our research is based on in-depth interviews with policymakers and educators in California, Connecticut, Florida, Georgia, Kentucky, Minnesota, New Jersey, South Carolina and Texas and in 25 districts in those states. The focus of this brief is to analyze the persistence and transformation of these new instructional guidance strategies, and the issues and challenges they have confronted.

Disciplines

Curriculum and Instruction | Educational Methods | Education Policy | Urban Education

\section{Comments}

The research presented in this policy brief is part of CPRE's Systemic Reform Study, a joint project conducted by the Policy Center of CPRE in conjunction with the National Center for Research on Teacher Learning (NCRTL). The project was funded by the U.S. Department of Education's Office of Educational Research and Improvement (OERI).

View on the CPRE website. 


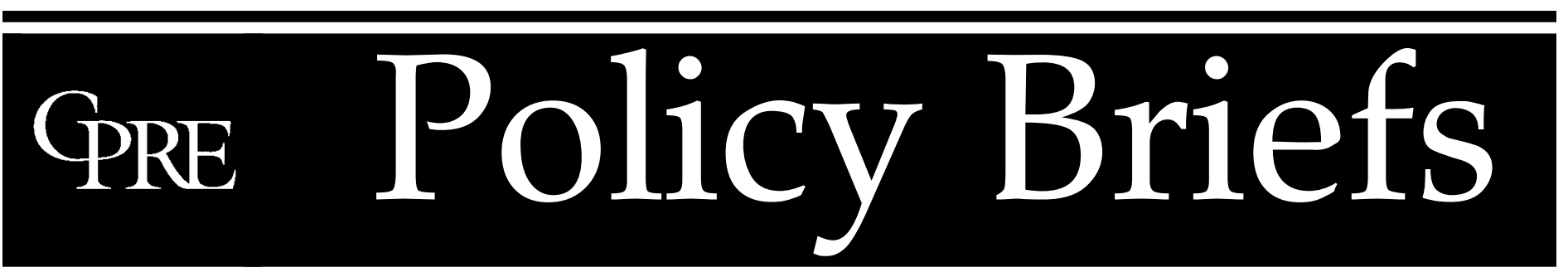

Reporting on issues and research in education policy and finance

Graduate School of Education — - University of Pennsylvania — RB-21-March 1997

\section{Persistence and Change: Standards-Based Systemic Reform in Nine States}

\section{by Diane Massell, Michael Kirst, and Margaret Hoppe}

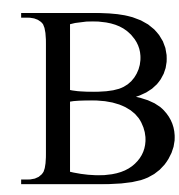

eginning in the mid- to late-1980s, state policymakers began to rethink their strategies for influencing curriculum and instruction in public education and adopted a policy strategy known as standards-based, systemic reform. While implemented in many different ways, in general these reforms have three key features:

- Challenging academic standards set by the state that would specify what all students should know and be able to do;

- Aligned policies, such as testing, accountability, teacher certification and professional development tied to the new, challenging standards; and

- Restructured educational governance to enable local teachers and schools to decide upon the specific instructional programs they would use to achieve the standards.

The rapidity with which the idea of standards-based, systemic reform took hold is remarkable, if not without historical precedent in the strongly networked field of education. Originally incubating quietly in the enclaves of professional subject-matter associations like the National Council of Teachers of Mathematics, efforts to set standards and articulate systemic reforms based on them were soon generated by nearly every state in the union (American Federation of Teachers, 1995) and a large array of urban, sub- urban and rural districts. Support came from the U.S. Department of Education, the National Science Foundation, and associations as diverse as the Business Roundtable, the National Governors' Association, and the American Federation of Teachers. Indeed, standards-based reform enjoyed high bipartisan consensus.

But this consensus began to fray somewhat as standardsbased reform ideas were translated into real policies. Federal policy efforts, notably Goals 2000 and the reauthorized Elementary Secondary Education Act, and some of the state reforms, occasioned significant debates about the possibility of greater control over localities' traditional autonomy in the area of curriculum. For example, Congressional and state-level policymakers strongly challenged such elements as the national panel envisioned by Goals 2000 that would have had the authority to certify the quality of states' standards.

This issue of CPRE Policy Briefs takes a look at how, against this backdrop, standards-based, systemic reforms evolved in nine states during the $1994-95$ period. Our research is based on in-depth interviews with policymakers and educators in California, Connecticut, Florida, Georgia, Kentucky, Minnesota, New Jersey, South Carolina and Texas and in 25 districts in those states. The focus of this brief is to analyze the persistence - and transformation — of these new instructional guidance strategies, and the issues and challenges they have confronted.

\section{CONSORTIUM FOR POLICY RESEARCH IN EDUCATION \\ University of Pennsylvania - Harvard University - Stanford University University of Michigan • University of Wisconsin-Madison}




\section{Steady, Incremental Progress}

In the nine states studied by CPRE, 1994-95 was characterized by a disjuncture between change-oriented political rhetoric and steady, incremental progress implementing the kinds of standards-based instructional guidance policies that have evolved over the past five to ten years. Policy rhetoric calling for greater free-market choices in education, smaller government, deregulation and the removal of categorical programs characterized both the state and federal level. There was notable discussion about and some action on establishing or expanding charter schools, enhancing public and private school choice, and reducing the size of state and local central office administration. But despite the strong antigovernment sentiment that sometimes challenged the idea of state standards, they remained important components of state policy. While no state undertook any major expansion in their standards-based guidance policies, our nine states for the most part stayed the course with these reforms.
Indeed, all of the nine states continued to develop or revise their academic content standards, as did twenty of the twenty-five districts we studied (see Table 1). To be sure, the pace of development was slow, with states in some cases taking more than five years to reach consensus on the structure of the standards' documents and their content. Turnovers in state leadership and financial problems also plagued some standard-setting efforts. For example, when New Jersey and Texas changed their governors, the standards initiatives begun under their predecessors were put on hold. But the delay proved temporary, and these stateslike others in our sample - proceeded with the reforms.

Many policymakers also saw improving state assessment programs as integral to standards-based reform. They set such goals as aligning their tests to new state or district standards, exchanging multiple-choice item formats with more authentic tasks, and replacing norm-referenced testing. Again, several of our study states and districts made incremental progress on these fronts (see Table 2). Connecticut, Kentucky, Georgia, Florida and
Texas succeeded in aligning one or more components of their testing programs to their standards. Connecticut, Kentucky, Minnesota and New Jersey integrated performance-based assessments into their statewide testing programs and, while California's governor vetoed a performance-based test, a new law would allow for some of these types of items in the next statewide test. During 1994-95, nine study districts experimented with performance assessments. While normreferenced testing was reduced in some sites, it was often not eliminated completely, and indeed, in Kentucky, was brought back into the testing program.

And, finally, some progress was made toward building the capacity of teachers to teach in ways that are compatible with the standards. For example, states such as Connecticut, Florida and Minnesota were actively revising their entry-level teacher certification processes to synchronize them with more challenging instruction, replacing the more customary basic skills, entrylevel tests. And, while certainly much more needs to be done, several states made notable efforts to align the pro-

\section{About the Authors}

Diane Massell is a Senior Research Associate at the Consortium for Policy Research in Education, located in the Graduate School of Education at the University of Pennsylvania. In the last few years, her work has focused on the evolution of standards-based reform, and the development of national, state and local standards policies, resulting in such publications as Setting National Content Standards, a special issue of Education and Urban Society. More recently, her work has focused on the efforts of a national consortium, the New Standards initiative, to create alternative ways of student assessment, and on a new study of the impacts of policy on local practice in 8 states.

Michael Kirst has been Professor of Education and Business Administration at Stanford University since 1969. Kirst has authored ten books, including Schools in Conflict: Political Turbulence in American Education (with Frederick Wirt, 1992), Federal Aid to Education, and his trade book Who Controls Our Schools (W.H. Freeman, 1984). As a policy generalist, Kirst has published articles on school finance politics, curriculum politics, intergovernmental relations, as well as education reform policies. Kirst is Co-Director of Policy Analysis for California Education (PACE), a California state education policy research group.

Margaret Hoppe is a consultant to CPRE. She has provided support on several CPRE projects including the evaluation of the Merck Institute initiative to reform science in four districts and an analysis of the linkages between state and urban initiatives in science and mathematics. 
Table 1

\section{Evolution of Curriculum Standards Documents in the 9 States}

\section{California _ In the mid-80s, state leaders focused on turning pre-existing state curriculum frameworks into more challenging, innovative documents. Revised frameworks in five subject areas were phased in over the next several years, and by 1994-95 were well-established. But that year the frameworks came under increasing scrutiny, in part because of the state's poor performance on the mathematics and reading portions of the National Association of Educational Progress test. In 1995 the state department of education (SDE) established task forces to revisit the frameworks. \\ - A 1995 law, Assembly Bill 265, required the development of new content and performance standards. Unlike frameworks, these standards will be set for every grade level, not just grade-level clusters. Plans are to submit the new standards for adoption by January, 1998 \\ Connecticut $\quad$ - In 1987 CT adopted the Common Core of Learning, which is a set of voluntary, general skills and outcomes for K-12 schooling. CT has produced voluntary guides to curriculum development since 1981. In 1994 a major report called for the development of content and performance standards, but the mandatory nature of this recommendation generated significant opposition and legislation failed. Currently, the SDE is revising its voluntary guides to curriculum development, which are scheduled for release in 1997.}

\section{Florida}

- The 1991 School Improvement and Education Accountability Act called for the revision of the state's pre-existing curriculum frameworks, following the development of more general state goals and standards in 1993.

. $\quad$ In 1996, after some delays, the state adopted frameworks in seven content areas.

\section{Georgia}

Kentucky

\section{Minnesota}

New Jersey

South Carolina
- In 1988, GA adopted the Quality Core Curriculum (QCC), laying out 72 basic competencies needed for graduation from high school. While law required periodic revisions, these were frequently delayed. But in 1992 English language arts standards were updated, as were science and mathematics standards in 1995-96.

- Efforts to revise the QCC continued in 1996, and new standards are scheduled for publication in 1997.

- In 1990, the KY Education Reform Act authorized the development of measurable state learning outcomes, and set the state on its course of developing 3 major curriculum guidance documents. Its "57 Academic Expectations" identifies broadly what students should know and be able to do. It is a pared down version of an earlier document containing the kinds of affective ${ }^{1}$ goals that critics felt intruded into personal values.

- "57 Academic Expectations" became the foundation for a second guidance document, the Transformations curriculum framework. However, in part because of KERA's high stakes accountability system, local educators felt that Transformations did not provide sufficient clarity and guidance. As a result, in 1996 the SDE published the third piece, more specific guidelines known as Core Content for Assessment.

- MN began its move towards a more results-oriented system in the 1980 s by initially embracing an OutcomesBased Education (OBE) approach. This was abandoned after sustained criticism of its affective goals and its high degree of prescriptiveness concerning local instructional practice.

- The Graduation Rule is the current state standards initiative, and contains 2 components: 1) the Basic Requirements, which are minimum skills required of all students for high school graduation, and 2) the Profile of Learning, which are more challenging standards. Students must demonstrate achievement on a portion of these standards.

- NJ began the process of developing standards in the late 1980s, but changes in state reform strategies as well as leadership prolonged the process. The current approach was established in a 1991 monitoring law requiring K-12 content standards. While drafts were completed two years later, an election with turnovers in the governor's and commissioner's office led to postponements and more revisions.

- Finally, in 1996 the state board of education adopted content standards in eight areas, and they have become the centerpiece of the governor's response to the state's long-running school finance suit.

In 1990 the SDE launched an effort to create curriculum frameworks. Math, visual and performing arts, and foreign languages were approved first, in 1993, since consensus for these subjects had been built on a variety of long-term national and local projects. Controversies, as well as resource constraints, led to delays in other subjects, but by 1996, English-language arts and science were adopted, and the last 3 frameworks (social studies, physical education, health and safety) are scheduled for completion in 1997.

- In 1984, TX adopted a set of "essential elements" in 12 core areas of knowledge. In 1992, an effort was undertaken to fashion them into standards for what students should know and be able to do, rather than descriptions of what teachers should do. While turnovers in state leadership led to a pause in the process, these efforts are back on track and are scheduled for completion in 1997.

1 Affective goals can include such items as students learn to respect themselves and others, or work well in groups. They are often associated with Outcomes-Based Education approaches. 
Table 2

Status of State Testing Programs in the 9 States, 1994-95

\begin{tabular}{|c|c|c|c|c|c|}
\hline State & $\begin{array}{l}\text { Assessment } \\
\text { Component }\end{array}$ & $\begin{array}{l}\text { Grades/Subjects } \\
\text { Tested }\end{array}$ & Item Format & $\begin{array}{l}\text { Aligned to } \\
\text { Standards }\end{array}$ & Other \\
\hline \multirow[t]{2}{*}{ California } & $\begin{array}{l}\text { California } \\
\text { Assessment of } \\
\text { Academic } \\
\text { Achievement (CAAA) }\end{array}$ & $\begin{array}{l}4-5,8,10 \\
\text { Math, reading, } \\
\text { writing, science, } \\
\text { history/social } \\
\text { sciences }\end{array}$ & Planning & Planned & $\begin{array}{l}\text { CLAS was vetoed in } \\
1994 \text {. The current } \\
\text { plan is to implement } \\
\text { CAAA statewide } \\
\text { testing component by } \\
1999 .\end{array}$ \\
\hline & $\begin{array}{l}\text { Pupil Incentive } \\
\text { Program } \\
\text { State provides } \\
\$ 5 / \text { pupil if districts } \\
\text { use norm-referenced } \\
\text { test of basic skills. }\end{array}$ & $\begin{array}{l}2-10 \\
\text { Reading, spelling, } \\
\text { writing, math }\end{array}$ & Local option & No & \\
\hline \multirow[t]{2}{*}{ Connecticut } & $\begin{array}{l}\text { Connecticut Mastery } \\
\text { Test }\end{array}$ & $\begin{array}{l}4,6,8 \\
\text { Math, language arts }\end{array}$ & Mixed & Yes & \\
\hline & $\begin{array}{l}\text { Connecticut } \\
\text { Academic } \\
\text { Performance Test }\end{array}$ & $\begin{array}{l}10 \\
\text { Math, language arts, } \\
\text { science, integrated } \\
\text { multidisciplinary }\end{array}$ & Mixed & Yes & \\
\hline \multirow[t]{4}{*}{ Florida } & $\begin{array}{l}\text { Florida Writing } \\
\text { Assessment Program }\end{array}$ & $\begin{array}{l}4,8,10 \\
\text { Writing }\end{array}$ & PB & Yes & \multirow{3}{*}{$\begin{array}{l}\text { An RFP was issued } \\
\text { for new grade } 4,8, \\
\text { and } 10 \text { test, to be } \\
\text { field tested in } 1997 . \\
\text { They will primarily be } \\
\text { multiple choice but } \\
\text { will also include } \\
\text { performance items. } \\
\text { The Grade } 10 \\
\text { Assessment Test will } \\
\text { be eliminated. } \\
\text { The High School } \\
\text { Competency Test will } \\
\text { be realigned to the } \\
\text { standards, and the } \\
\text { Writing Assessment } \\
\text { will continue. }\end{array}$} \\
\hline & $\begin{array}{l}\text { Grade Ten } \\
\text { Assessment Test }\end{array}$ & $\begin{array}{l}10 \\
\text { Math, } \\
\text { communications }\end{array}$ & FR & No & \\
\hline & $\begin{array}{l}\text { High School } \\
\text { Competency Test }\end{array}$ & $\begin{array}{l}11 \\
\text { Math, } \\
\text { communications }\end{array}$ & FR & No & \\
\hline & $\begin{array}{l}\text { District Norm- } \\
\text { Referenced Tests } \\
\text { Districts must } \\
\text { administer and } \\
\text { submit results to the } \\
\text { state. }\end{array}$ & $\begin{array}{l}4,8 \\
\text { Math, reading }\end{array}$ & Local Option & No & \\
\hline \multirow[t]{2}{*}{ Georgia } & $\begin{array}{l}\text { lowa Test of Basic } \\
\text { Skills/TAP }\end{array}$ & $\begin{array}{l}3,5,8,11 \\
\text { Math, reading, with } \\
\text { science and social } \\
\text { studies }\end{array}$ & FR & No & \multirow{2}{*}{$\begin{array}{l}\text { A proposal to } \\
\text { eliminate Curriculum- } \\
\text { Based Assessments } \\
\text { was defeated, but } \\
\text { they were made } \\
\text { voluntary. Issue of } \\
\text { elimination will be } \\
\text { revisited. }\end{array}$} \\
\hline & $\begin{array}{l}\text { Curriculum-Based } \\
\text { Assessment }\end{array}$ & $\begin{array}{l}3,5,8,11 \\
\text { Math, language arts, } \\
\text { science, social } \\
\text { studies, writing }\end{array}$ & Mixed & Yes & \\
\hline Kentucky & $\begin{array}{l}\text { Kentucky Instructional } \\
\text { Results Information } \\
\text { System (KIRIS) }\end{array}$ & $\begin{array}{l}4,8,12 \\
\text { Math, reading, } \\
\text { science, social } \\
\text { studies, writing }\end{array}$ & $\begin{array}{l}\text { PB and Portfolios in } \\
\text { math and writing }\end{array}$ & Yes & $\begin{array}{l}\text { Changes in KIRIS for } \\
\text { 1995-96 will include: } \\
\text { (1) CTB Terra Nova in } \\
\text { math }(3,6,9) ;(2) \\
\text { multiple choice item; } \\
\text { (3) KIRIS spread out } \\
\text { across more grade } \\
\text { levels; (4) } \\
\text { Performance events } \\
\text { were eliminated; (5) } \\
\text { Math portfolios were } \\
\text { removed pending } \\
\text { more research and } \\
\text { development. }\end{array}$ \\
\hline
\end{tabular}


Table 2 (continued)

Status of State Testing Programs in the 9 States, 1994-95

\begin{tabular}{|c|c|c|c|c|c|}
\hline State & $\begin{array}{l}\text { Assessment } \\
\text { Component }\end{array}$ & $\begin{array}{l}\text { Grades/Subjects } \\
\text { Tested }\end{array}$ & Item Format & $\begin{array}{l}\text { Aligned to } \\
\text { Standards }\end{array}$ & Other \\
\hline \multirow[t]{3}{*}{ Minnesota } & $\begin{array}{l}\text { Graduation Rule } \\
\text { Two components: } \\
\text { a) Basic } \\
\text { requirements. } \\
\text { Districts can select } \\
\text { any minimum } \\
\text { competency test to } \\
\text { meet these basic } \\
\text { skills standards }\end{array}$ & $\begin{array}{l}\text { a) Basic } \\
\text { requirements. } \\
\text { Reading and math } \\
\text { in the 9th grade. }\end{array}$ & Local Option & Planned & $\begin{array}{l}\text { Graduation Rule to } \\
\text { be implemented in } \\
\text { 1998. State } \\
\text { designed test } \\
\text { districts can use for } \\
\text { Basic Requirements. } \\
\text { State sponsored } \\
\text { development of } \\
\text { performance-based }\end{array}$ \\
\hline & $\begin{array}{l}\text { b) Profile of } \\
\text { Learning. Districts } \\
\text { can select which of } \\
\text { these more } \\
\text { challenging } \\
\text { standards to assess, } \\
\text { and use any } \\
\text { assessments they } \\
\text { wish. }\end{array}$ & $\begin{array}{l}\text { b) Profile of } \\
\text { Learning. } \\
\text { Interdisciplinary, } \\
\text { anytime between } \\
\text { grades } 9 \text { and } 12\end{array}$ & & & $\begin{array}{l}\text { can satisfy different } \\
\text { Profile of Learning } \\
\text { standards. Writing } \\
\text { and science will be } \\
\text { added to the Basic } \\
\text { Requirements. }\end{array}$ \\
\hline & $\begin{array}{l}\text { Planning, Evaluation } \\
\text { and Reporting } \\
\text { Process (PER) } \\
\text { Districts must } \\
\text { assess sample of } \\
\text { students in } 3 \\
\text { grades. }\end{array}$ & $\begin{array}{l}\text { Local Option for } \\
\text { both grade levels } \\
\text { and subjects. }\end{array}$ & Local Option & No & $\begin{array}{l}\text { PER set to expire in } \\
1996 \text { and will be } \\
\text { replaced with the } \\
\text { Graduation Rule. }\end{array}$ \\
\hline \multirow[t]{2}{*}{ New Jersey } & $\begin{array}{l}\text { Early Warning Test } \\
\text { (EWT) }\end{array}$ & $\begin{array}{l}4,8 \\
\text { Math, reading, } \\
\text { writing }\end{array}$ & Mixed & $\begin{array}{l}\text { Planned for 4th } \\
\text { grade }\end{array}$ & $\begin{array}{l}\text { Tests are evolving } \\
\text { from basic-skill, } \\
\text { multiple-choice } \\
\text { format to include } \\
\text { more performance- } \\
\text { based elements; 4th } \\
\text { grade EWT under } \\
\text { development. }\end{array}$ \\
\hline & $\begin{array}{l}\text { High School } \\
\text { Proficiency Test }\end{array}$ & $\begin{array}{l}11 \\
\text { Math, reading, } \\
\text { writing }\end{array}$ & & & \\
\hline \multirow[t]{2}{*}{ South Carolina } & $\begin{array}{l}\text { Basic Skills } \\
\text { Assessment } \\
\text { Program }\end{array}$ & $\begin{array}{l}3,6,8,10 \\
\text { Math, reading, } \\
\text { science, with writing } \\
\text { sample }\end{array}$ & Mixed & Planned & $\begin{array}{l}\text { K-3 Continuous } \\
\text { Assesment Project } \\
\text { piloted, } 36 \text { sites } \\
\text { piloting performance } \\
\text { assessments. }\end{array}$ \\
\hline & $\begin{array}{l}\text { Metropolitan } \\
\text { Achievement Test } 7\end{array}$ & $4,5,7,9,11$ & FR & No & \\
\hline \multirow[t]{2}{*}{ Texas } & $\begin{array}{l}\text { Texas Assessment } \\
\text { of Academic Skills } \\
\text { (TAAS) }\end{array}$ & $\begin{array}{l}3-8,10 \\
\text { Math, reading, } \\
\text { writing, science, } \\
\text { social studies }\end{array}$ & Mixed & Yes & $\begin{array}{l}1995 \text { TAAS test } \\
\text { released to allow } \\
\text { public scrutiny. }\end{array}$ \\
\hline & $\begin{array}{l}\text { TAAS End-of- } \\
\text { Course Exams }\end{array}$ & $\begin{array}{l}9-12 \\
\text { Alegbra I, Biology I }\end{array}$ & Mixed & & $\begin{array}{l}\text { End-of-Course } \\
\text { assessments will be } \\
\text { piloted for English II, } \\
\text { US History in } 1996 .\end{array}$ \\
\hline
\end{tabular}

KEY: Item Format: FR = fixed response; PB = performance based. Mixed Scoring: NRT = norm-referenced; CRT = criterion-referenced; $\mathrm{PL}=$ performance level. 
fessional development of experienced teachers with standards-based reforms. One strategy for doing so was to involve teachers in the development of new policies and programs; Minnesota, for example, relied on over 1,000 teachers to create performance assessments tied to its Profile of Learning standards. Another promising trend was the emergence of teacher subject-matter or grade level networks, supported not just by states, but also by universities and national or federal entities. For example, in Connecticut, Georgia, New Jersey, South Carolina and Texas, the National Science Foundation's Statewide Systemic Initiatives spurred the creation of mathematics and science networks. The university system in California, in conjunction with the State Department of Education, launched Subject Matter Projects - teacher networks focused on specific disciplines - ten years ago; as of 1995, there were projects in 11 curricular areas in 90 sites.

What accounts for the steady, incremental progress of standards-based reform? While certainly each state is unique, many common, cross-cutting themes did emerge. At the state-level, education and business communities continued to be supportive of this general policy strategy. For example, Texas business leaders, school administrators, and other education groups lobbied to keep the state test-based accountability system in place, even in a climate of strong legislative support for deregulation and decentralization that might have led to the elimination of such mandates. California teachers supported a successful attempt to authorize a new state assessment system, and Minnesota teachers were supportive of the general idea of increased graduation standards.
The external stimulus and support provided by national associations and projects was also crucial to the stability and continuation of reform. State and local policymakers reported drawing upon the resources and efforts of the groups that developed national standards. Policymaker associations, such as the National Governors' Association, facilitated the exchange of knowledge about reform strategies. Seven of our states (CA, CT, FL, GA, $\mathrm{KY}, \mathrm{NJ}$, and TX) developed their mathematics and science standards with the support of their National Science Foundation's Statewide Systemic Initiative projects. Indeed, while subject-matter revisions in most areas had been stalled for years in Georgia, work in science and mathematics forged ahead because of such external support. States used Goals 2000 and private foundation resources to support their own versions of standardsbased change. Indeed, the nationalization of education reform initiatives is not a new story, following in the footsteps of the school finance equalization initiatives of the 1970s and the excellence reforms of the 1980s, which swept from state-to-state with remarkable speed and consistency.

Opposition to standards-based reform also took national channels, funneled through small but well-organized traditional Christian and conservative groups. These were not the only groups criticizing or opposing standards-based reform, but they were the most vocal and influential. These groups rallied against OutcomesBased Education (OBE), standards, and performance-based assessment, often perceiving them to be both extensions of government influence and vehicles for liberal philosophies. They had some success, but most often this took the form of modifying the content of standards-based reform, not dismantling it.
In fact, perhaps the most critical element facilitating the continuation of standards-based reform was the effort by policymakers to establish a balance between often-competing poles of reform, a subject we take up in the next section.

\section{Balancing New and Old Approaches}

Reforms received the strongest criticisms when they focused on new goals to the seeming exclusion of basic skills or traditional teaching methods. Indeed, particularly early on in their reform efforts, some states' standards policies deemphasized-or even totally rejected-familiar teaching methods like phonics, emphases on basic skills, and conventional testing practices. California's mathematics and English-language arts frameworks, for example, incorporated newer pedagogical approaches, as did its extensive performance-based assessment (the California Learning Assessment System, or CLAS). Even more so than California, Kentucky's policymakers embraced a wholly performance-based assessment system that was tied to a strong system of rewards and sanctions. In fact, the Kentucky Instructional Results and Information System included such ambitious performance assessment technologies as student group performance tasks and collections of student work into mathematics and writing portfolios. Multiple choice items were discarded from its accountability calculations in 1993. These innovations often generated considerable controversy. In the 1980s, Minnesota's reform initiatives were strongly tied to a mandate for OBE, as were Kentucky's original 75 Valued Learner Outcomes. OBE often emphasized such affective goals as "students should work well in groups," "have high self-esteem," 
or "be tolerant of others." Critics charged that these objectives were difficult, if not impossible, to measure, and inappropriately intruded into the personal lives and values of students and their families.

As criticisms and expert reviews of these more unconventional approaches to standards and assessments mounted, policymakers listened and made numerous modifications but, importantly, did not completely toss out the new practices. Instead, they responded by seeking a better balance between newer and older approaches. For example, Kentucky pared back its "75 Valued Learner Outcomes" to "57 Academic Expectations" based on more narrowly construed notions of academic knowledge. It also planned to return multiple choice items to the accountability index to enhance certain technical aspects of the system, dropped the group performance tasks from the accountability system, and added a norm-referenced mathematics component which was reasonably aligned to state standards. But it retained the writing portfolio as well as the performance-based character of the other KIRIS components. Even in California, where the backlash to reform was more severe than in our other study states, state laws passed in 1994 and 1995 enable developers to mix innovations with more traditional approaches should they choose to do so. Minnesota replaced its OBE approach with a Graduation Rule, which contains a set of basic skills standards, called "Basic Requirements," and more challenging "Profile of Learning" standards.

Balance was the theme of the day in districts as well. For example, in one Georgia district that had received strong challenges to OBE initiatives, a respondent said:
We realized that we had created the perception that we had abandoned the basics for untried educational experiments. A major theme emerged that had to do with balance: performance assessment and traditional assessment, cooperative learning, and independent learning.

To some reform advocates at both the state and district levels, these efforts to reach a balance signified defeatthey saw the compromises in standards and assessments as undermining the most innovative approaches to teaching and learning, and as a slip back to old, ineffective ways. To others, these changes represented positive outcomes, because from the outset standards-based reform was intended to be an interactive dialogue among state policymakers, the education profession, and the public over the content of what students should know and be able to do. Will the "balanced" approaches facilitate incremental but progressive changes in teaching and learning, or will they send mixed signals to schools and teachers that enable people to sustain the status quo of low expectations and poor performance? Will "balance" mean a thoughtful integration of approaches, or erratic combinations of traditional practices one day and new the next? Future research should attend to these questions.

\section{Local Response to State Standards-based Reforms}

As noted, most of the districts in our sample were actively pursuing their own standards-based curricular and instructional change. While state policies often influenced local efforts in this direction, it is important to note that many districts led or substantially elaborated upon state initiatives. For example, while the California framework documents in use during 199495 were organized by grade-level clusters (K-3, 4-8, 9-12), three out of the four study districts created guidance documents for each grade level. The extent to which California districts embraced the philosophy of state frameworks varied because of local administrators' and teachers' own interpretations, political environment, and other factors. Such differences demonstrate once again that the extension of governmental authority at one level is not necessarily a "zero sum" game (Fuhrman and Elmore, 1990). Rather than stunting local initiative and decisionmaking, state action could stimulate (see also Spillane et al., 1995), but it did not uniformly determine, districts' and schools' own curricular and instructional activities.

Indeed, the impact of state standards initiatives on local policies was often more subtle and indirect than what critics who were fearful of aggressive state or federal control over instruction forecasted. Contrary to concerns that standards-based reforms would overextend state and federal authority, in practice these policies fit well within the decentralized American tradition. For instance, local staff in nearly all the sites typically regarded the state's standards as only one of many resources they used to generate their own, more detailed curricular guidance policies and programs. They reported turning to multiple sourcesthe state, but also to national standards groups, other districts, and their own communities - for input to develop their own, tailored guidance documents.

Ironically and, again, contrary to most conservative critics' concerns, most educators wanted more-not lessexternal guidance and support for in- 
struction than they received from the state or other groups. For example, the most frequent complaint about state standards centered on their broad, general nature and the implicit or explicit assumption ${ }^{1}$ that district and school staff would have the capacity, resources, time, and expertise to flesh them out into a local curriculum. Said one California administrator about his state's frameworks - which, comparatively speaking, were more detailed than most- "The state stuff is full of fluff and sweeping general statements, and is not much help." Local educators in Kentucky felt that they lacked the time or knowledge to create the kinds of curricular and instructional programs they needed to meet the new state expectations; consequently, they successfully demanded that the state provide them with more specific guidance and support.

\section{Building Capacity for Reform}

Many approaches to standards-based reform call for numerous changes in teaching and educational administration. With more challenging academic standards for students and the devolution of decisionmaking to schools under site-based management initiatives, teachers and administrators are being asked not only to teach more challenging curriculum to all students but also to establish new relationships with each other and with parents. These new roles require new skills and knowledge from many teachers and administrators.

At the beginning of the standards movement, policymakers focused their energies on developing new instructional guidance instruments, such as standards and assessments. They paid less attention to building the capacity to enact reform in classrooms and schools (Massell and Fuhrman, 1994). Now, several years into reform, these questions are being addressed more systematically in a number of states. As noted above, state policymakers were making changes in initial licensure and certification to align them to reform goals, and expanding some promising professional development initiatives for experienced educators.

But despite these efforts, training activities too often remained loosely linked to larger reform initiatives. For example, state policymakers often asked districts to engage in processes to identify needs and then align their professional development plans to these needs; some viewed this as a meaningless and unproductive paper exercise. In most cases, our states were not highly directive and specific about professional development activities. In part, this may be attributed to states' generally low levels of support for professional development activities.

Furthermore, support for professional development is often a premier target during cutting times. For example, while Florida and Georgia have long provided financial backing for professional development activities, budget reductions led the Florida legislature to eliminate funding for summer teacher institutes, while Georgia's Institutes for Learning were reduced from a budget of $\$ 3$ million to $\$ 500,000$. Minnesota eliminated a required district set-aside for professional development at the behest of districts and the teachers' union, who had not seen increases in the state general aid formula for several years.

District respondents in South Carolina, California and Connecticut noted that cuts in state aid forced them to rely on periodic, one-day workshops rather than the more sustained kinds of activities that many believe are necessary for meaningful reform. Indeed, district staff were often struggling to patch together temporary solutions to help teachers meet the challenges of reform, resulting occasionally in very superficial approaches which did not address gaps in teachers' content knowledge or problems with their teaching. For example, a curriculum specialist in one district devised a scope and sequencing guide that simply matched pages in the textbook to the statewide tests.

While a few districts tried to ensure that their professional development menu was aligned to local or state standards initiatives, professional development offerings more typically addressed a diverse set of goals and objectives. This variation in professional development increased in districts with site-based management, raising questions about meeting districtwide capacity-building needs and about achieving cost-efficiencies with the funds so dispersed. As one district administrator in Minnesota noted, "Staff development funds are up for grabs - schools can do whatever they want; teachers can do whatever they want."

Some districts sought innovative solutions. One district in Florida redesigned its professional development strategy to give staff long-term support in one area of concentration rather than short-term training on a series of new topics. As the superintendent noted, "Let's not train everybody on everything but longer on a few things. Don't jam anything down their throats - identify certain areas and follow up." We also found districts in Georgia, South Carolina, and Minnesota providing more extended forms 
of training through the use of summer institutes, customized graduate courses, short-term sabbaticals, and teacher instructional centers.

Yet, overall, local respondents often expressed concerns about the overwhelming needs for building capacity to meet the stringent demands of standards-based reform. It was another motivation, for some, to deliberately choose a more incremental approach to change. Capacity remains a persistent challenge of reform.

\section{The Equity Challenge}

Equity has been a primary component of the policy rhetoric in behalf of standards-based reform, oft-repeated in the mantra of "more challenging standards for all students." Yet policymakers' early efforts concentrated on establishing the policy infrastructure for general education reform; little attention was given to those with special needs.

When attention to equity did emerge, policymakers frequently focused on the state testing program as a chief policy mechanism for bringing all students under the standards tent. In our sample states, Kentucky and California moved the farthest down this road by passing uniform assessment policies requiring every student to take the state test. While Kentucky allowed test exemptions for non-English speakers in the United States for less than two years, it had very extensive requirements that everyone else be tested and that their scores be included in the accountability program and reporting system. For example, special needs students had to be tested with adaptations consistent with the normal delivery of instruction, not adaptations solely for the purposes of the test. Students with severe disabilities who could not function within the regular curriculum were to participate in "alternative portfolio" assessments, but their scores would still be included in the accountability program (Council of Chief State School Officers, 1996). Similarly, California took several steps to include all students in its assessment program by creating, for instance, Spanish-language CLAS tests. New Jersey planned to include special education students in their new fourthgrade test, noting the high level of exemptions in the state's high-stakes graduation test.

But, for the most part, attention to equity issues within the context of standards-based reform remained episodic and weak. With a few notable exceptions $^{2}$, desegregation and school finance policies were pursued as separate, independent initiatives. Representatives of students with diverse needs, especially educators of students with disabling conditions, often were not involved in developing new standards policies. In most of our states, as in most of the nation (see Council of Chief State School Officers, 1995), opportunity-to-learn standards specifying the various learning conditions to which all students should have access were not on the policy agenda. South Carolina and Georgia saw opportunity-to-learn concerns as a states' rights issue and refused to address them in their Goals 2000 plans to the federal government. In New Jersey, by contrast, the new state leadership openly embraced opportunity-to-learn standards as part of a strategic plan to bundle equity, a long-running dispute over school funding, and standards. But this was the exception rather than the rule.

In sum, very little progress has been made overall in addressing the many equity issues that emerge from efforts to raise the educational standards for all students. Building bridges to these special needs students will be crucial to the success, and long-term viability, of these reforms.

\section{Conclusion}

Standards-based, systemic reform has made impressive gains in recent years, despite the many difficulties inherent in such a sustained and complex effort. Indeed, policymakers on both sides of the political aisle and across all levels of government - federal, state, and local - have broadly agreed on the merits and worth of this approach to school change. As a consequence, states have persisted with the strategy despite substantial turnovers in leadership, criticisms about the content of particular standards and assessment policies, and real cuts in educational spending.

But policymakers must confront several immediate issues and challenges if they are to improve these reforms. One which came through repeatedly in our study is the need to provide additional, and more sustained, support to teachers and local administrators. Teachers need access to richer opportunities on an ongoing basis, and they need direction and support from central office staff. But some policymakers have ignored the role of district administrators and local boards, frequently conceiving of them as impediments to be bypassed rather than as partners in the change effort. Yet these administrators are often pivotal conduits for reform, interpreting its substance and providing - or not providing, as the case may be - both organizational structures and resources that affect whether and how reform policies are translated into school and classroom practices (see Spillane et al., 1995). 
Complicating the district and school administrators' roles is the decentralization occurring via site-based management and decisionmaking. One of the lessons of recent reforms is that it is not desirable for either teachers or administrators to completely reinvent curricula or assessments school-byschool. This demands rethinking the question of the districts' role in reform. What can districts do to facilitate exchanges, provide support, and fight the insularity that often plagues schools and teachers?

Second, equity strategies were often not well thought out, particularly in regard to the standards reforms. If the goal of achieving higher standards for all students is not to be hollow rhetoric, resources and attention must be focused on how to best serve all students in a challenging academic environment. Equally important are addressing the problems that impinge on students' abilities to meet new academic goals, problems that teachers and administrators cope with every day-poverty, hunger, homelessness, violence, drug dependencies, and more. These problems are growing, and in some districts are crowding out teachers', administrators', and students' capacity to attend to the very difficult educational tasks at hand.

Third, by 1994-95 the content of the reforms themselves had moved back towards the middle of the change spectrum, with policymakers trying to balance those forces calling for far-reaching and radical innovation with those forces calling for adherence to traditional practices. This more moderate stance may help standards move forward politically. But questions remain about whether such balancing advances the instructional goals of reform, i.e., rigorous, demanding curricula that stimulate students' abilities to think critically and to problem-solve.
Will standards policies that incorporate both new and old goals make sense in the classroom? Or will they send mixed signals, and simply reinforce the status quo?

And, finally, the commitment of nongovernmental and national change agents to the standards-based reform agenda has been remarkable and sustaining. Together these groups have set in motion a dense array of professional networks that, if well-coordinated and conceived, connect people and provide important support to teachers and school administrators. But we also found that they could add an additional layer of complexity to the system, and send local educators in diverse and sometimes competing directions. Policymakers at the state and local level should seek ways to encourage greater coordination among these various activities.

\section{Endnotes}

1. States intentionally provided standards that were broadly-worded enough to allow significant room for local curricular decisionmaking. Politically, state policymakers did not want to exacerbate fears and concerns - i.e., that they were going to exert a heavy, controlling hand over local curricula. Equally compelling for many state administrators was a strategic theory about motivating meaningful local change. Some of our state respondents expressed the belief that, for the standards to truly take hold, local educators would need to make them appropriate for their own contexts. In addition to this empowerment and buy-in strategy, state policymakers also believed that the instructional goals they were trying to foster required that they not provide overly specified curriculum guidance documents, lest they lead back to the kind of lock-step, rote instruction that they were trying to change.

2. Kentucky must be mentioned in this regard. Its school finance lawsuit in 1989 was the motivating force behind its entire standards-based reform movement.

\section{References}

(AFT) American Federation of Teachers. (1995). Making Standards Better: A Fifty State Progress Report on Efforts to Raise Academic Standards. Washington, DC: Author.

Council of Chief State School Officers (1995). Status Report: State Systemic Education Improvements. Washington, DC: Author.

Council of Chief State School Officers (1996). State Student Assessment Program Database. Washington, DC: Author.

Fuhrman, S.H. and R.E. Elmore (1990). "Understanding local control in the wake of state education reform." Educational Evaluation and Policy Analysis 12(1): 82-96.

Massell, D. and S.H. Fuhrman (1994). Ten Years of State Education Reform:, 1983-1993. New Brunswick, NJ: Consortium for Policy Research in Education.

Spillane, J., C.L. Thompson, C. Lubienski, L. Jita, and C. B. Reimann (1995). The Local Government Policy System Affecting Mathematics and Science Education in Michigan: Lessons from Nine School Districts. Draft report. East Lansing, MI: Consortium for Policy Research in Education. 


\section{More on the Subject from CPRE}

\section{The Bumpy Road to Education Reform}

Jennifer O'Day, Margaret E. Goertz, and Robert E. Floden

(No. RB-20-June 1996)

This issue of CPRE Policy Briefs identifies five challenges that confront educators and policymakers as they develop higher standards and other policies and structures to support improved student and teacher learning. It also describes strategies used by a few states and localities to address some of these challenges. The brief draws on findings of a threeyear study of standards-based reform conducted by CPRE researchers in California, Michigan and Vermont.

Studies of Education Reform: Systemic Reform (July 1995) reports results of a three-year study conducted by the Consortium for Policy Research in Education and the National Center for Research on Teacher Learning. The study team reviewed the current literature on systemic reform, commissioned four papers about the preparation and professional development of teachers, and conducted case studies of 12 reforming schools in California, Michigan, and Vermont. Findings are documented in a three-volume technical report.

Volume I: Findings and Conclusions summarizes the literature review and commissioned papers, the study methodology, and the education reform strategies and policies in the three study states. It identifies some com- mon lessons for policymakers who take a standardsbased approach to instructional improvement. (168 pp. \$17.50)

Volume II: Case Studies contains the 12 case studies. It includes detailed information on state policies, and describes and analyzes reform efforts in the schools and districts studied. (148 pp. \$15.00)

\section{Volume III: Technical Appendix —Research Design and Methodology contains a description of the study methodology and copies of the interview protocols and teacher surveys used in the data collection. (102 pp. $\$ 10.00)$}

The three volume set is available at the reduced price of $\$ 35.00$.

Teacher Professional Development Profiles, a product of CPRE's 50-state study on professional development, are available through the Consortium for Policy Research in Education. Please call 215-573-0700, x0 for further information. In Spring 1997, copies of the teacher development profiles will be available on CPRE's home page at:

\section{http://www.upenn.edu/gse/cpre/}

\section{Ordering Instructions}

To obtain copies of CPRE Research Reports, write:

CPRE Publications

Graduate School of Education

University of Pennsylvania

3440 Market Street, Suite 560

Philadelphia, PA 19104-3325

All orders must be prepaid with U.S. funds drawn from U.S. banks; make checks payable to Trustees of the University of Pennsylvania.

To obtain copies of CPRE Policy Briefs, write to the address above or email us at cpre@nwfs.gse.upenn.edu. There is no charge for single copies. 